\title{
Concentration and speciation of arsenic in an insect feeding on the leaves of Pteris vittata
}

\author{
Xiaoming Wan ${ }^{1,2, *}$, Mei Lei ${ }^{1,2}$, Tongbin Chen ${ }^{1,2}$ \\ 1 Institute of Geographic Sciences and Natural Resources Research, Chinese Academy of Sciences, Beijing 100101, China \\ 2 University of Chinese Academy of Sciences, Beijing 100089, China
}

\section{H I G H L I G H T S}

- Hawk moth showed foraging preference to $P$. vittata fronds with low As concentation.

- Hawk moth can not exclude As by excretion. - The main As speciation of hawk moth is As(III)-SH.

\section{ARTICLE INFO}

Article history:

Received December 8, 2020

Revised February 24, 2021

Accepted April 12, 2021

Keywords:

Arsenic speciation

Bioinsecticide

Hawk moth

Herbivore

Hyperaccumulator
GRAPHICAL ABSTRACT
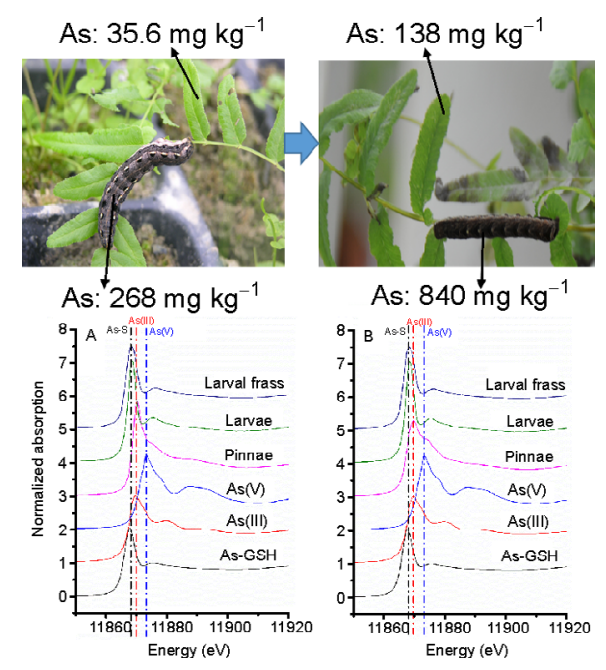

A B S T R A C T

The development of an effective and green bioinsecticide is a research hotspot. This study demonstrated the possibility of using an arsenic (As) hyperaccumulator as a bioinsecticide. When the As concentration in the Pteris vittata fronds exceeded $138 \mathrm{mg} \mathrm{kg}^{-1}$, the larva of the hawk moth (Theretra clotho) displayed apparent preference to lower-As-concentration $P$. vittata fronds. The As concentration in the larva body was as high as $850 \mathrm{mg} \mathrm{kg}^{-1}$. Such high concentration of As in the larva body might have been the case that $T$. clotho lacks a process to exclude As. The larval frass showed an As concentration of only $1 \%-4 \%$ of that in the larva body. The predominant As species in the larva body and frass was As(III)-SH. The percentage of $\mathrm{As}$ (III)-SH was slightly higher in the frass than that in the larval body. Chelation with thiols may be a universal detoxification mechanism for As in both plants and insects. In general, the adoption of $P$. vittata as a bioinsecticide should be feasible. However, the exact processes to achieve this goal still need further study. The mechanism of different animals to detoxify As is another interesting research topic.

(C) Higher Education Press 2021

\section{Introduction}

* Corresponding author

E-mail address: wanxm.06s@igsnrr.ac.cn (X. Wan)
Insecticides are widely applied in farmlands to prevent herbivores from damaging crops. They have increased crop 
yield but also generated environmental problems (Sharma et al., 2020). They persist in the environment for years because of their nonbiodegradability. These chemicals enter the ecosystem, hampering the sensitive environmental equilibrium through bioaccumulation (Ko et al., 2020).

The utilization of bioinsecticides instead of chemical ones may increase crop production without compromising human health (Sharma et al., 2020). The development of an effective and green bioinsecticide has become a research hotspot (Ramasamy et al., 2020). Ten plant species containing bioactive compounds, such as essential oils, saponins, tannins, alkaloids, phenolics, flavonoids, alkenes, and terpenoids, have been identified to possess potential as bioinsecticides (Purwani et al., 2015).

Pteris vittata is a well-known arsenic (As) hyperaccumulator. This species has a super As accumulating ability, with the maximum aboveground As concentration reaching $2 \%$ (w:w) (Ma et al., 2001; Chen et al., 2002). Growing on soil with limited As concentration $\left(9 \mathrm{mg} \mathrm{kg}{ }^{-1}\right), P$. vittata can still accumulate a considerable amount of As $\left(785 \mathrm{mg} \mathrm{kg}^{-1}\right)$ in its aboveground parts (Chen et al., 2002). Furthermore, it has a large biomass and can grow up to $2 \mathrm{~m}$ in height and 2250 $\mathrm{kg} \mathrm{hm}^{-2}$ in weight. This species has been utilized to extract As from the contaminated soil in China, America, Japan, and Europe, achieving a removal rate of $18 \%$ As per year (Chen et al., 2018).

$P$. vittata can absorb As in its biomass but also in the surrounding soil to a concentration that is nearly twice as high as that of nearby sites. This trait can provide a competitive advantage over other local plants by impairing the growth of local As-sensitive plant species (Jaffe et al., 2018).

One of the evolution theories for the hyperaccumulating characteristics is that excess toxic elements in hyperaccumulators can prevent herbivores (Manara et al., 2020). The current study aimed to confirm the hypothesis that excess As in $P$. vittata could act as an insecticide. Lead arsenate was widely used as an insecticide for apple and cherry orchards, and chromated copper arsenate was used as wood preservative through the early 1900s (Hughes et al., 2011). These inorganic arsenates have been found in the biomass, exudates, and litter of $P$. vittata (Zhang et al., 2002; Barbafieri et al., 2017), which can effectively kill insects, fungi, and bacteria.

Intercropping of $P$. vittata with other cash crops has become a scenario to sustainably reuse the contaminated soil. This process can gradually clean the environment and at the same time bring in economic benefits (Wan et al., 2017b; Ma et al., 2018). If the hypothesis can be confirmed, intercropping with $P$. vittata may act as a biocontrol method for insecticides.

Hawk moth (Theretra spp.) is a class of commonly found insects that feed on agricultural crops and ornamental plants, such as eddoe (Colocasia esculenta L. Schott), grape (Vitis spp.), and garden balsam (Impatiens balsamina L.) when these insects are in the larval stage (Nagamine et al., 2019). The feeding of these insects on ferns has also been reported (Mehltreter et al., 2003). However, their feed on $P$. vittata, a well-known As hyperaccumulator, has not been reported yet.

In this study, the larvae and larval frass of $T$. clotho feeding on the pinnae of $P$. vittata were collected and their As concentration and speciation were analyzed. The leaves bitten and leaves not bitten by $T$. clotho were collected separately. This study was performed to elucidate the growth and foraging behavior of $T$. clotho affected by As-enriched $P$. vittata and the accumulation and metabolization of As in $T$. clotho.

\section{Materials and methods}

\subsection{Collection of $T$. clotho and $P$. vittata leaves}

T. clotho was found to feed on $P$. vittata in the greenhouse. Eggs of $T$. clotho might have been brought in by some newly bought Sedum spectabile seedlings. T. clotho was first only found on sporelings with limited As concentration (Fig. 1A). The sporelings with low As concentration were growing on the soil collected from a clean farmland in Shimen County, Hunan Province, and its basic properties are described in Table 1.

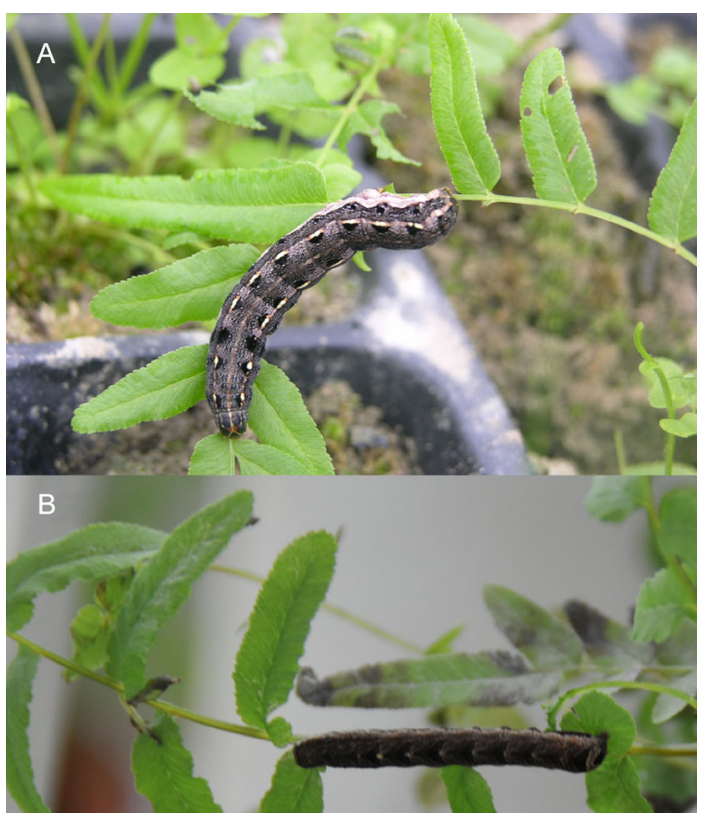

Fig. 1 Photo of the mollusk on the pinna of Pteris vittata with (A) low and (B) high arsenic (As) concentrations.

After T. clotho was spotted, the Sedum seedlings were removed and only $P$. vittata was kept in the greenhouse. Later, $T$. clotho was also found on the $P$. vittata sporelings exposed to high concentrations of As (Fig. 1B). The high-As soil was collected from a contaminated farmland close to a mining area in Shimen County, Hunan province, and its basic properties are described in Table 1.

$P$. vittata at the height of $\sim 15 \mathrm{~cm}$ and the 5 th instar T. clotho larvae feeding on these leaves were separately collected, freeze-dried, and stored in a refrigerator for further analysis. 
Table 1 Properties of soils with low and high As used in the experiment.

\begin{tabular}{lll}
\hline Index & Low-As soil & High-As soil \\
\hline Total N (\%) & $0.10 \pm 0.01 \mathrm{~b}$ & $0.17 \pm 0.01 \mathrm{a}$ \\
Total P (\%) & $0.09 \pm 0.01 \mathrm{a}$ & $0.08 \pm 0.01 \mathrm{a}$ \\
Total K (\%) & $1.85 \pm 0.07 \mathrm{a}$ & $1.90 \pm 0.05 \mathrm{a}$ \\
Organic matter (\%) & $1.90 \pm 0.15 \mathrm{a}$ & $2.21 \pm 0.20 \mathrm{a}$ \\
Cation exchange capacity $\left(\mathrm{cmol} \mathrm{kg}^{-1}\right)$ & $14.0 \pm 1.2 \mathrm{a}$ & $13.6 \pm 0.5 \mathrm{a}$ \\
pH & $7.6 \pm 0.1 \mathrm{a}$ & $7.7 \pm 0.2 \mathrm{a}$ \\
As concentration $\left(\mathrm{mg} \mathrm{kg}^{-1}\right)$ & $9.5 \pm 0.8 \mathrm{~b}$ & $75.6 \pm 6.2 \mathrm{a}$ \\
\hline
\end{tabular}

The pinnae of $P$. vittata without any bite marks were also separately collected and freeze-dried for further analysis. After being freeze-dried, the T. clotho larvae were weighed on a microbalance with a sensitivity of $1 \mu \mathrm{g}$. The larval frass of $T$. clotho was also collected. Ten replicates were used for these biological samples.

\subsection{Chemical analysis}

The X-ray absorption near-edge structure (XANES) was used to determine the As speciation in the fronds of $P$. vittata and in the body and frass of the T. clotho larvae. Immediately prior to XANES measurement, the freeze-dried samples were carefully ground into powder and packed in a $3 \mathrm{~cm} \times 0.7 \mathrm{~cm}$ sample holder. The $X$-ray absorption spectra of As were recorded in fluorescence mode at the X-ray absorption fine structure station on the beam line 14W1 of the SSRF (Shanghai, China). The detailed procedure was provided in one of our earlier studies (Wan et al., 2017a). Analytically pure $\mathrm{NaAsO}_{2}$ and $\mathrm{Na}_{2} \mathrm{HAsO}_{4} \cdot 7 \mathrm{H}_{2} \mathrm{O}$ were respectively used as reference compounds for inorganic $\mathrm{As}(\mathrm{III})$ and $\mathrm{As}(\mathrm{V})$. As(III)tris-glutathione, which was synthesized through adding a 10 fold molar excess of reduced L-glutathione to a sodium arsenite solution, was used to model As(III) coordinated to three thiols. The software Athena was applied in normalizing XANES spectra, which was analyzed through linear combination fitting (LCF) with the Athena program.

To determine the total concentrations of As in the $P$. vittata, insects, and frass, the biological samples were ground and digested with a mixture of $\mathrm{HNO}_{3} / \mathrm{HClO}_{4}(4 / 1, \mathrm{v} / \mathrm{v})$ (Chen et al., 2002). An atomic fluorescence spectrometer was used to determine the As concentrations (Haiguang AFS-2202, Beijing Kechuang Haiguang Instrumental Co., Ltd., Beijing, China). The certified standard reference materials for the plants (GSV-2) from the China National Standard Materials Center were digested and analyzed together with the samples. The recovery rates of As were 95\%-101\%.

\subsection{Literature collection}

To compare the behavior of $T$. clotho with other insects, we searched the Web of Science database using the keywords of arsenic and insect, and collected other insects' data of As accumulation. With these data available, we only chose the literature providing specific As concentration of the feed (plant or soil) and As concentration of the animal body, and left those aside with incomplete data set. The records on As concentration and speciation in insects were very limited. Only four studies contained full data sets of As concentration and speciation in both feed and larval body. Therefore, earthworms were also incorporated into the comparison among animals, because its As accumulation and detoxification mechanisms have been reported much more than that for insects.

\subsection{Data processing}

The bioaccumulation factor (BCF) of As by insects or by earthworms was calculated as follows:

$$
\mathrm{BCF}=\mathrm{C}_{\text {animal }} / \mathrm{C}_{\text {feed }},
$$

where $\mathrm{C}_{\text {animal }}$ is the concentration of As in the insects or earthworms, and $\mathrm{C}_{\text {feed }}$ is the concentration of As in the feed (plants for insects but soil for earthworms).

To reflect the excretion efficiency of As by animals, excretion rates were calculated as follows:

$$
\mathrm{ECF}=\mathrm{C}_{\text {frass }} / \mathrm{C}_{\text {animal }},
$$

where $\mathrm{C}_{\text {frass }}$ is the concentration of As in the larval frass, and $\mathrm{C}_{\text {animal }}$ is the concentration of As in the insects or earthworms.

PASW® Statistics 18.0 was used to statistically analyze the data of As concentrations. Significance level was set to an error probability of 0.05 . Differences in As concentrations among the biomaterials were tested using ANOVA (Tukey). Values represent mean \pm standard deviation $(n=10)$. Figures were made using Origin 9.

\section{Results and discussion}

\subsection{Effect of As on the growth and foraging behavior of} T. clotho

The growth of $T$. clotho feeding on $P$. vittata with higher concentration of As was not as good as that with lower 
concentration of As (Fig. 1). T. clotho feeding on $P$. vittata fronds with higher As concentrations (138 $\mathrm{mg} \mathrm{kg}^{-1}$ ) showed a significantly lower average bodyweight (Table 2). No imago was observed in the greenhouse perhaps due to the high toxicity of excess As in the T. clotho larvae.

Another study examined the growth of scale insect (Saissetia neglecta, a greenhouse pest) infesting on $P$. vittata exposed to different As concentrations. The results showed that greater As concentrations in the fronds of $P$. vittata (610 $\mathrm{mg} \mathrm{kg}^{-1}$ ) resulted in a death rate of $55.0 \%$ for $S$. neglecta (Mathews et al., 2009). Similarly, supplying diet spiked with different concentrations of As (ranging from $0.75 \mathrm{mg} \mathrm{kg}^{-1}$ to 75 $\mathrm{mg} \mathrm{kg}^{-1}$ ) caused a mortality of army moth (Mamestra configurata Walker) ranging from $3 \%$ to $48 \%$ (Andrahennadi and Pickering, 2008). These values indicated that high concentrations of As in $P$. vittata fronds could kill insects feeding on them.

In terms of the foraging behavior of $T$. clotho for $P$. vittata with low As concentrations (35.6-40.1 $\mathrm{mg} \mathrm{kg}^{-1}$ ), apparently no difference in the As concentrations of $P$. vittata was found between the plant with insect bites and that without insect bites (Table 2). By contrast, for $P$. vittata with higher As concentrations, the pinna with insect bites showed a significantly lower As concentration than that without insect bites (Table 2). This result implied that the foraging behavior of T. clotho was not sensitive to As when the As concentration was approximately $40 \mathrm{mg} \mathrm{kg}^{-1}$, but sensitive to As when the As concentration of the feed exceeded $138 \mathrm{mg} \mathrm{kg}^{-1}$ (Table 2).

The As hyperaccumulation may have evolved as a defense strategy against insect herbivory (Hörger et al., 2013). Rathinasabapathi et al. (2007) proposed that high concentration of arsenite in $P$. vittata may act as a deterrent. In the current study, the As in $P$. vittata also affected the foraging behavior of $T$. clotho but only at high concentrations. Both being insects, $T$. clotho is holometabolous while grasshopper is hemimetabolous. The larvae of $T$. clotho might be less sensitive to As than grasshopper.

Considering these earlier studies and the current study (Rathinasabapathi et al., 2007; Andrahennadi and Pickering, 2008; Mathews et al., 2009), we suggest that $P$. vittata can keep insects away by either poisoning nonsensitive species or deterring sensitive species. In addition, the secondary products induced in response to arsenite treatment might also be the feeding deterrent (Rathinasabapathi et al., 2007). In one of our earlier studies (Cai et al., 2020), $P$. vittata extractions could act as antimicrobial agent due to its chlorogenic acid. Whether these compositions can also deter insects needs further study. And, the relationship between insect deterrence and the evolution of hyperaccumulator requires further investigation too.

Reports on the toxicity of As to terrestrial insects are still rare. Several studies on the toxicity of As to aquatic insects have been performed. The results showed that the 4-d LC ${ }_{50}$ of four larvae was in the range of $1.5-113 \mathrm{mg} \mathrm{L}^{-1}$ (Champeau et al., 2017), suggesting significant difference among the various orders of insects. Furthermore, Champeau et al. (2017) found that insects from the acidic stream $(\mathrm{pH} 5.9)$ were more sensitive to As-spiked water than those from the neutral stream ( $\mathrm{pH} 7.4) .1$

Earthworms, which are annelids, have been extensively investigated for their foraging behavior in As-treated and clean soils. Two earthworm species (Lumbricus rubellus and Dendrodrillus rubidus) from uncontaminated soils $(<0.1$ $\mathrm{mg} \mathrm{As} \mathrm{kg}^{-1}$ ) could efficiently avoid soil treated with sodium arsenate, while those from a contaminated area (8983 $\mathrm{mg} \mathrm{As} \mathrm{kg}^{-1}$ ) were less ready to avoid As (Langdon et al., 2001b). Langdon et al. (2001a) showed that earthworms (L. rubellus) from mining soil, containing high concentrations of As (8000 mg kg-1), only discriminated significantly against soil containing concentrations of sodium arsenate above 5000 $\mathrm{mg} \mathrm{kg}^{-1}$ by moving into the uncontaminated soil. Below this concentration, the earthworms did not discriminate between clean and As-treated soils.

Therefore, As concentrations of the feed and also the habitat environment are important to determine the reactions of insects and annelids to environmental As.

\subsection{Concentration of As in the larvae and larval frass}

The results indicated that generally when the As concentration in soil was higher, the As concentration in $P$. vittata was also higher, accompanied by higher As concentration in $T$. clotho (Table 2).

$P$. vittata growing on clean soil with As concentration lower than $10 \mathrm{mg} \mathrm{kg}^{-1}$ showed a pinna As concentration of approximately $35.6 \mathrm{mg} \mathrm{kg}^{-1}$. By contrast, $T$. clotho larva feeding on these pinnae showed a concentration of As of 268 $\mathrm{mg} \mathrm{kg}^{-1}$ (Table 3). In soil with higher As concentration, $P$. vittata indicated a considerably higher As concentration, accompanied also by a higher As concentration in the larval body. The highest concentration of As in T. clotho got to 840 $\mathrm{mg} \mathrm{kg}^{-1}$. Compared with the larva body, the larval frass of $T$. clotho showed a much lower concentration of As. The highest concentration of As in the larval frass of $T$. clotho was less than $12 \mathrm{mg} \mathrm{kg}^{-1}$. The difference of the As concentrations in the larval frass was not significant among the samples

Table 2 Effect of As on the foraging behavior and dry weight of Theretra clotho.

\begin{tabular}{lll}
\hline Index & Low-As soil & High-As soil \\
\hline As concentration of Pteris vittata pinna with insect bites $\left(\mathrm{mg} \mathrm{kg}^{-1}\right)$ & $35.6 \pm 4.6 \mathrm{~b}$ & $138 \pm 38.5 \mathrm{a}$ \\
As concentration of $P$. vittata pinna without insect bites $\left(\mathrm{mg} \mathrm{kg}^{-1}\right)$ & $40.1 \pm 6.2 \mathrm{~b}$ & $208 \pm 31.7 \mathrm{a}$ \\
Average dry weight of $T$. clotho $(\mathrm{mg})$ & $40.3 \pm 1.0 \mathrm{a}$ & $10.7 \pm 1.1 \mathrm{~b}$ \\
\hline
\end{tabular}


obtained from the low As area and those collected from the high As area.

Generally, with an increase of the As concentration in the feed, the As concentration in the larvae body increased (Fig. 2). Such elevation was not found in the larval frass. Furthermore, compared with other insects, T. clotho showed a significantly higher BAF and lower ECR (Table 3). These phenomena implied that $T$. clotho may lack a certain mechanism to exclude As, resulting in the accumulation of a high concentration of As in the body. Furthermore, Lepidoptera apparently has a stronger capacity to accumulate As than
Homoptera, which showed a significantly higher BAF of As than Homoptera (Table 3, Fig. 2). The reasons for the varied As metabolisms of the different orders of insects need further investigation.

Reports on the accumulation of As in insects are rare, but earthworms have been studied extensively on their metabolisms of As (Table 4). Contrary to insects, earthworms showed strong adaptability to As-enriched environment. The BCF of As was in the order of insects>earthworms, and within insects, Lepidoptera>Homoptera (Tables 3 and 4) (Watts et al., 2008). The ECR of As was opposite to that of BCF, that is,

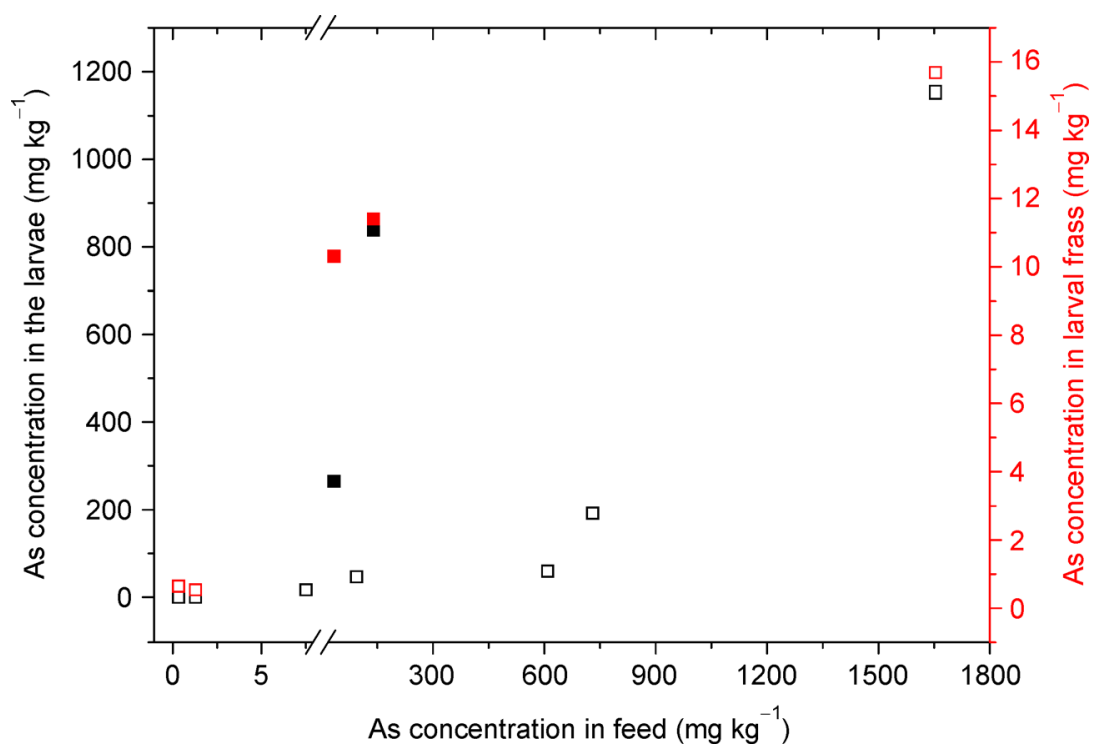

Fig. 2 Relationship between the As concentrations of feed and in the insect larvae and frass (solid black squares indicate As concentration in the Theretra clotho larvae, and solid red squares indicate As concentration of the T. clotho frass).

Table 3 Comparison between T. clotho and other insects in the As concentration in feed, larvae, and larval frass.

\begin{tabular}{|c|c|c|c|c|c|c|c|}
\hline \multirow{2}{*}{$\begin{array}{l}\text { Animal } \\
\text { T. clotho } \\
\text { (Lepidoptera) }\end{array}$} & \multirow{2}{*}{$\begin{array}{l}\text { Type of feed } \\
\text { P. vittata }\end{array}$} & \multirow{2}{*}{$\begin{array}{l}\begin{array}{l}\text { As in feed } \\
\left(\mathrm{mg} \mathrm{kg}^{-1}\right)\end{array} \\
138 \\
35.6\end{array}$} & \multirow{2}{*}{$\begin{array}{l}\begin{array}{l}\text { As in larvae } \\
\left(\mathrm{mg} \mathrm{kg}^{-1}\right)\end{array} \\
840 \\
268\end{array}$} & \multicolumn{2}{|c|}{$\begin{array}{l}\text { As in the larvalBCF } \\
\text { frass }\left(\mathrm{mg} \mathrm{kg}^{-1}\right)\end{array}$} & \multirow{2}{*}{$\begin{array}{l}\text { ECR } \\
0.01\end{array}$} & \multirow{2}{*}{$\begin{array}{l}\text { Reference } \\
\text { This study }\end{array}$} \\
\hline & & & & 11.4 & 6.09 & & \\
\hline \multirow{2}{*}{$\begin{array}{l}\text { Callopistria } \\
\text { floridensis G. } \\
\text { (Lepidoptera) }\end{array}$} & P. vittata & 1655 & 1154 & 15.7 & 0.70 & 0.01 & \multirow[t]{2}{*}{ Jaffe et al., 2019} \\
\hline & $\begin{array}{l}\text { Nephrolepis } \\
\text { exaltata }\end{array}$ & 1.24 & 2.09 & 0.53 & 1.69 & 0.25 & \\
\hline $\begin{array}{l}\text { Mamestra } \\
\text { configurata } \\
\text { Walker } \\
\text { (Lepidoptera) }\end{array}$ & $\begin{array}{l}\text { Arsenate- } \\
\text { spiked diet }\end{array}$ & 7.5 & 18 & $\mathrm{~N} / \mathrm{A}$ & 2.4 & $\mathrm{~N} / \mathrm{A}$ & $\begin{array}{l}\text { Andrahennadi } \\
\text { and Pickering, } \\
2008\end{array}$ \\
\hline $\begin{array}{l}\text { Bombyx mori } \\
\text { Linnaeus } \\
\text { (Lepidoptera) }\end{array}$ & Morus alba & 0.34 & 0.71 & 0.67 & 2.09 & 0.94 & Wan et al., 2017 \\
\hline $\begin{array}{l}\text { S. neglecta } \\
\text { (Homoptera) }\end{array}$ & & 730 & 194 & $\mathrm{~N} / \mathrm{A}$ & 0.27 & $\mathrm{~N} / \mathrm{A}$ & $\begin{array}{l}\text { Mathews et al., } \\
2009\end{array}$ \\
\hline
\end{tabular}

${ }^{*} \mathrm{~N} / \mathrm{A}$ indicates not applicable 
insects < earthworms (Tables 3 and 4). Insects ingesting plants showed significantly higher BCF and lower ECR than earthworms ingesting soil. This phenomenon may be due to the higher bioavailability of As in plant tissues than As in soil and the more adaptive metabolism of earthworms than insects.

First, As in P. vittata mostly exists as As(III), which has been regarded as the most mobile species of As (Su et al., 2008). However, in soil, most As are precipitated or adsorbed with iron/manganese oxides, which are considered to have low mobility (Kim et al., 2014).

Second, although earthworms showed a wide range of As concentrations, the As concentrations in earthworms never exceeded the As concentrations found in soil (Geiszinger et al., 1998). Earthworm, which has adapted to the soil environment enriched with As, could exclude As by eliminative behavior. Due to the lack of acclimation process to As, $T$. clotho and other insects may have no such mechanism of excluding As.

\subsection{Speciation of As in worms}

For $P$. vittata from high-As soil or low-As soil, the main As species in the pinnae of $P$. vittata was arsenite [As(III)], with few existing as arsenate $[\mathrm{As}(\mathrm{V})]$ (Figs. 3 and 4$)$. The As speciation in $T$. clotho was apparently different from its feed, mainly thiol-chelated As(III), with limited amount of As(III). By contrast, in the larval frass, only the thiol-chelated form of As [As(III)-SH] was found, with no As(V) or As(III) detected.

According to the literature, few As(III)-SH was found in the fronds of $P$. vittata when the plant was exposed to extremely high concentration of bioavailable As ( $\mathrm{Li}$ et al., 2009). Chelation with thiols was regarded as a mechanism to lower the mobility or reactivity of As in plants (Li et al., 2009). Detoxification through chelation with thiols was also feasible in $P$. vittata, but only when the exposed As concentration was very high (Li et al., 2009). P. vittata showed an apparently higher percentage of As(III)-SH when containing a higher total As concentration (Wan et al., 2017a). In the current study,

Table 4 As concentrations in the soil, earthworms, and feces.

\begin{tabular}{|c|c|c|c|c|c|c|c|}
\hline Earthworm & Type of feed & $\begin{array}{l}\text { As in soil } \\
\left(\mathrm{mg} \mathrm{kg}^{-1}\right)\end{array}$ & $\begin{array}{l}\text { As in the } \\
\text { earthworms } \\
\left(\mathrm{mg} \mathrm{kg}^{-1}\right)\end{array}$ & $\begin{array}{l}\text { As in the feces } \\
\text { of earthworms } \\
\left(\mathrm{mg} \mathrm{kg}^{-1}\right)\end{array}$ & $\mathrm{BCF}$ & ECR & Reference \\
\hline \multirow{7}{*}{$\begin{array}{l}\text { Dendrodillus } \\
\text { rubidus }\end{array}$} & Soil & 16 & 7 & 11 & 0.44 & 1.57 & \multirow[t]{15}{*}{ Watts et al., 2008} \\
\hline & Soil & 1005 & 317 & 994 & 0.32 & 3.14 & \\
\hline & Soil & 255 & 19 & 274 & 0.07 & 14.42 & \\
\hline & Soil & 331 & 17 & 229 & 0.05 & 13.47 & \\
\hline & Soil & 284 & 18 & 290 & 0.06 & 16.11 & \\
\hline & Soil & 289 & 38 & 291 & 0.13 & 7.66 & \\
\hline & Soil & 913 & 74 & 720 & 0.08 & 9.73 & \\
\hline \multirow{8}{*}{$\begin{array}{l}\text { Lumbricus } \\
\text { rubellus }\end{array}$} & Soil & 16 & 7 & 11 & 0.44 & 1.57 & \\
\hline & Soil & 2980 & 595 & 2488 & 0.20 & 4.18 & \\
\hline & Soil & 1573 & 257 & 1330 & 0.16 & 5.18 & \\
\hline & Soil & 12466 & 359 & 923 & 0.03 & 2.57 & \\
\hline & Soil & 439 & 40 & 284 & 0.09 & 7.10 & \\
\hline & Soil & 289 & 11 & $N / A^{\#}$ & 0.04 & na & \\
\hline & Soil & 5141 & 203 & 1173 & 0.04 & 5.78 & \\
\hline & Soil & 2871 & 571 & 1853 & 0.20 & 3.25 & \\
\hline \multirow{6}{*}{$\begin{array}{l}\text { Lumbricus } \\
\text { rubellus }\end{array}$} & Soil & 22.0 & 4.0 & $\mathrm{~N} / \mathrm{A}^{\#}$ & 0.18 & $\mathrm{~N} / \mathrm{A}^{\#}$ & \multirow{6}{*}{$\begin{array}{l}\text { Geiszinger et al., } \\
1998\end{array}$} \\
\hline & Soil & 66.4 & 6.4 & & 0.10 & & \\
\hline & Soil & 48.8 & 4.8 & & 0.10 & & \\
\hline & Soil & 5.0 & 3.2 & & 0.64 & & \\
\hline & Soil & 45.7 & 8.2 & & 0.18 & & \\
\hline & Soil & 79.7 & 17.9 & & 0.22 & & \\
\hline
\end{tabular}

${ }^{\#}$ N/A indicates not applicable. 

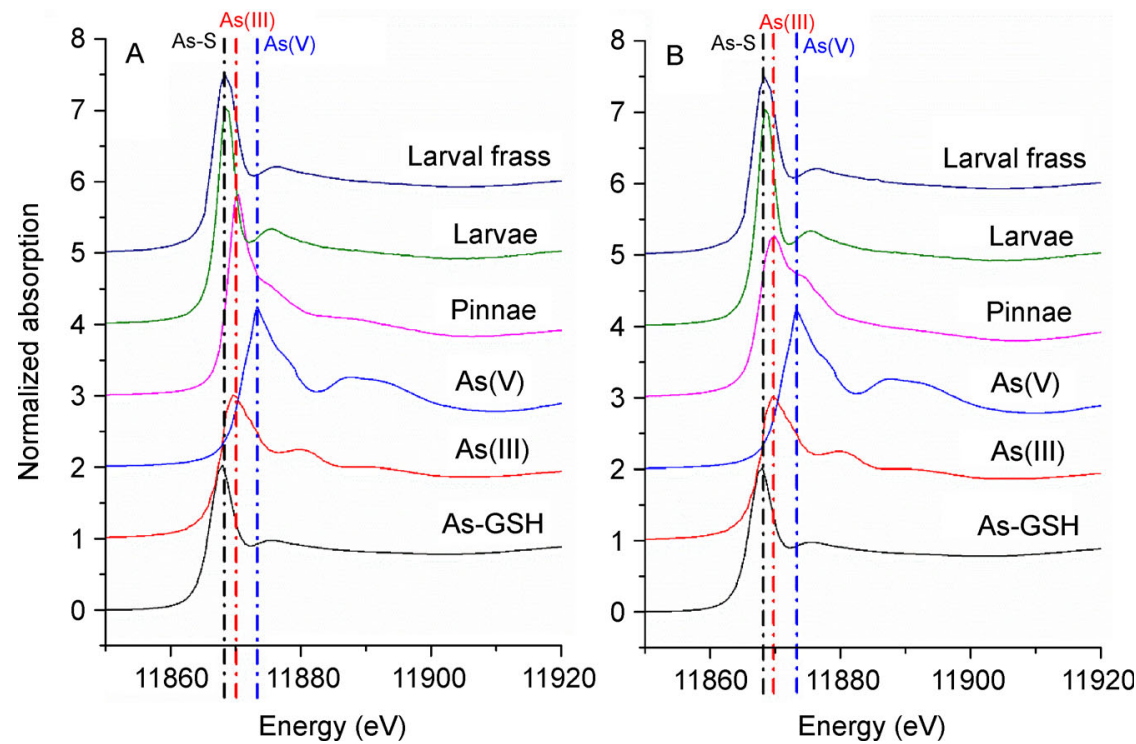

Fig. 3 XANES spectra of As in the standard materials and $P$. vittata pinna, larvae, and larval frass from areas with (A) low and (B) and high As.
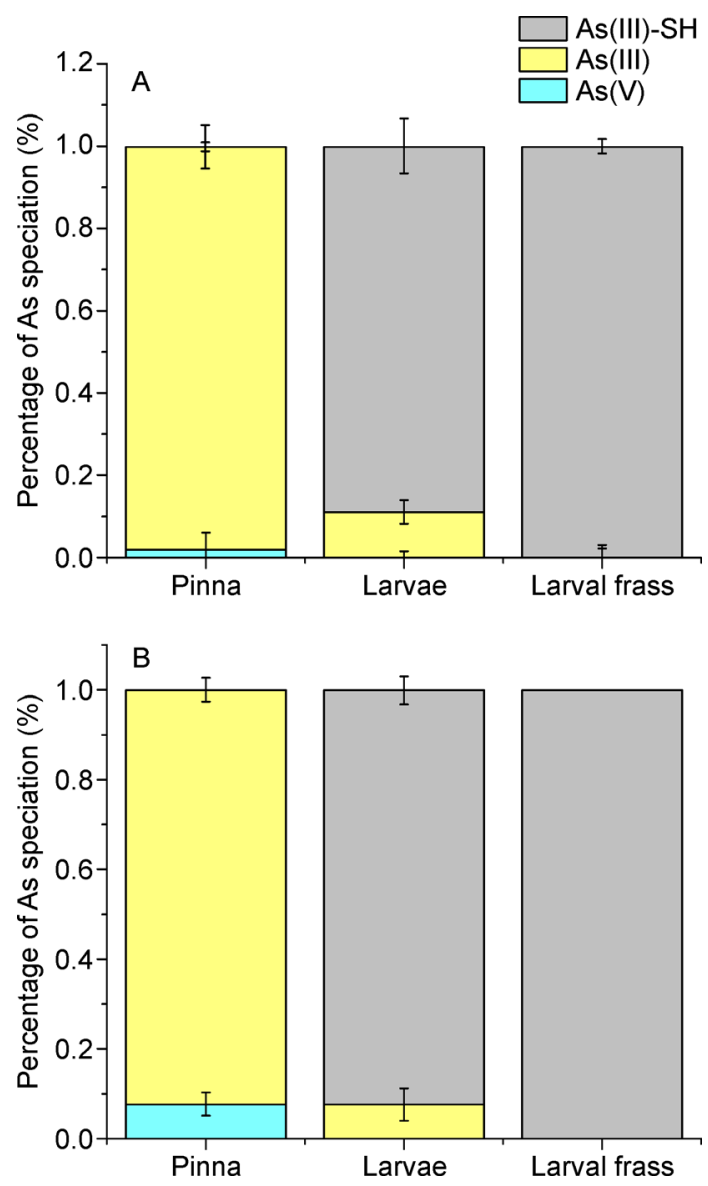

Fig. 4 Arsenic speciation of $P$. vittata pinna, larvae, and larval frass from the areas with (A) low and $(B)$ high As.

As(III) was predominant in the pinna, indicating that the As exposure was not high enough to induce the chelation of As with thiols in $P$. vittata.
The high percentage of $\mathrm{As}(\mathrm{III})-\mathrm{SH}$ in the larval body and frass indicated that the As exposure to T. clotho was high enough to trigger the detoxification reaction for T. clotho. In the larval frass, only chelated As was detected, and no As(III) was found. This result indicated that the excluding strategy, which works for bacteria and earthworms, did not work for T. clotho.

Earthworms showed different As speciation with T. clotho (Table 5). The As species in earthworms include As(V), As(III), and limited organic arsenic (Watts et al., 2008). Interestingly, two earthworms indicated largely varied As speciation in the body. As $(\mathrm{V})$ was the predominant species in L. rubellus, and As(III) dominated in D. rubidus. The percentage of organic As was apparently higher in D. rubidus than that in L. rubellus. The two earthworm species may adopt different measures to handle high concentrations of toxic substances in the environment. $D$. rubidus adopted chelation, and $L$. rubellus adopted oxidation as the main strategy to turn As(III) to a less active species.

\subsection{Application potential}

The current study indicated that $P$. vittata growing on soils with high and low As killed T. clotho that accidentally fed on this hyperaccumulator. This phenomenon may be due to the high As concentration in the larvae body that led to the death of the larvae. Whether other metabolites in this unique fern have also played a role in this process remains unknown. Based on the current study and available literature, planting $P$. vittata with other crops may function as a bioinsecticide. The detailed procedure to achieve this goal needs further study. Intercropping hyperaccumulators with crops may be feasible as an ongoing and environment-friendly strategy to keep herbivores away. Furthermore, using insects as a biomonitoring material might be another potential application direction, as stated by (Skaldina et al. (2020)). 
Table 5 Comparison of As speciation in T. clotho and other insects or earthworms (\%)

\begin{tabular}{|c|c|c|c|c|c|c|c|}
\hline Animal & $\mathrm{As}(\mathrm{V})$ & $\mathrm{As}(\mathrm{III})$ & As-SH & Arsenobetaine & $\begin{array}{l}\text { Dimethylated } \\
\text { arsenic }\end{array}$ & $\begin{array}{l}\text { Monomethylated } \\
\text { arsenic }\end{array}$ & References \\
\hline T. clotho & $\mathrm{Nd}^{*}$ & 7.7 & 92.3 & $N / A^{\#}$ & $\mathrm{~N} / \mathrm{A}$ & $N / A$ & This study \\
\hline $\begin{array}{l}\text { Armyworm } \\
\text { (M. configurata } \\
\text { Walker) }\end{array}$ & $\mathrm{Nd}$ & 12 & 89 & $\mathrm{~N} / \mathrm{A}$ & $\mathrm{N} / \mathrm{A}$ & $\mathrm{N} / \mathrm{A}$ & $\begin{array}{l}\text { Andrahennadi } \\
\text { and Pickering, } \\
2008\end{array}$ \\
\hline $\begin{array}{l}\text { Earthworm } \\
\text { (L. rubellus) }\end{array}$ & 62 & 24 & & 13 & 0.2 & 0.7 & Watts et al., 2008 \\
\hline $\begin{array}{l}\text { Earthworm } \\
\text { (D. rubidus) }\end{array}$ & 16 & 44 & & 35 & 0.8 & 0.2 & Watts et al., 2008 \\
\hline
\end{tabular}

${ }^{*} \mathrm{Nd}$ indicates not detected; ${ }^{\text {NN}} / \mathrm{A}$ indicates not applicable.

\section{Conclusion}

The larvae of an accidentally imported hawk moth species ( $T$. clotho) were found feeding on the As hyperaccumulator $P$. vittata. This fern grown on soils with high and low As killed $T$. clotho before its maturation. Investigation on the As concentration of this insect and its feces indicated that $T$. clotho enriched a high concentration of As $\left(840 \mathrm{mg} \mathrm{kg}^{-1}\right)$ in the body but a small amount was excreted. The As concentration in the larval frass was less than $12 \mathrm{mg} \mathrm{kg}^{-1}$. Analysis of the As speciation displayed that chelation was the main detoxification method used by $T$. clotho. Furthermore, comparison between $T$. clotho and other insects or earthworms indicated that insects, especially Lepidoptera, lacked the ability to detect or exclude As, whereas earthworms showed a strong capacity to avoid and exclude As. The evolution patterns of different insects to sense and react with As require further studies.

\section{Acknowledgments}

Financial support was provided by the National Natural Science Foundation of China (Grant No. 42077136) and grants from the Youth Innovation Promotion Association of the Chinese Academy of Sciences (No. 2017075).

\section{References}

Andrahennadi, R., Pickering, I.J., 2008. Arsenic accumulation, biotransformation and localisation in bertha armyworm moths. Environmental Chemistry 5, 413-419.

Barbafieri, M., Pedron, F., Petruzzelli, G., Rosellini, I., Franchi, E., Bagatin, R., Vocciante, M., 2017. Assisted phytoremediation of a multi-contaminated soil: Investigation on arsenic and lead combined mobilization and removal. Journal of Environmental Management 203, 316-329.

Cai, W., Chen, T.B., Lei, M., Wan, X.M., 2020. Effective strategy to recycle arsenic accumulated biomass of Pteris vittata with high benefits. Science of the Total Environment 756, 143890.

Champeau, O., Cavanagh, J.A.E., Sheehan, T.J., Tremblay, L.A., Harding, J.S., 2017. Acute toxicity of arsenic to larvae of four New Zealand freshwater insect taxa. New Zealand Journal of Marine and Freshwater Research 51, 443-454.

Chen, T., Lei, M., Wan, X., Yang, J., Zhou, X., 2018. Arsenic Hyperaccumulator Pteris vittata L. and Its Application to the Field. In: Luo, Y., Tu, C., eds. Twenty Years of Research and Development on Soil Pollution and Remediation in China. Springer Singapore, Singapore, pp. 465-476.

Chen, T.B., Wei, C.Y., Huang, Z.C., Huang, Q.F., Lu, Q.G., Fan, Z.L., 2002. Arsenic hyperaccumulator Pteris vittata L. and its arsenic accumulation. Chinese Science Bulletin 47, 902-905.

Geiszinger, A., Goessler, W., Kuehnelt, D., Francesconi, K., Kosmus, W., 1998. Determination of arsenic compounds in earthworms. Environmental Science \& Technology 32, 2238-2243.

Hörger, A.C., Fones, H.N., Preston, G.M., 2013. The current status of the elemental defense hypothesis in relation to pathogens. Frontiers in Plant Science 4, 395.

Hughes, M.F., Beck, B.D., Chen, Y., Lewis, A.S., Thomas, D.J., 2011. Arsenic exposure and toxicology: a historical perspective. Toxicological Sciences 123, 305-332.

Jaffe, B.D., Ketterer, M.E., Shuster, S.M., 2018. Elemental allelopathy by an arsenic hyperaccumulating fern, Pteris vittata L. Journal of Plant Ecology 11, 553-559.

Kim, E.J., Yoo, J.C., Baek, K., 2014. Arsenic speciation and bioaccessibility in arsenic-contaminated soils: sequential extraction and mineralogical investigation. Environmental Pollution 186, 29-35.

Ko, E., Choi, M., Shin, S., 2020. Bottom-line mechanism of organochlorine pesticides on mitochondria dysfunction linked with type 2 diabetes. Journal of Hazardous Materials 393, 122400.

Langdon, C.J., Piearce, T.G., Meharg, A.A., Semple, K.T., 2001a. Resistance to copper toxicity in populations of the earthworms Lumbricus rubellus and Dendrodrilus rubidus from contaminated mine wastes. Environmental Toxicology and Chemistry 20, 23362341.

Langdon, C.J., Piearce, T.G., Meharg, A.A., Semple, K.T., 2001b. Survival and behaviour of the earthworms Lumbricus rubellus and Dendrodrilus rubidus from arsenate-contaminated and non-con- 
taminated sites. Soil Biology \& Biochemistry 33, 1239-1244.

Li, X.W., Lei, M., Chen, T.B., Wan, X.M., 2009. Roles of sulfur in the arsenic tolerant plant Adiantum capillus-veneris and the hyperaccumulator Pteris vittata. Journal of the Korean Society for Applied Biological Chemistry 52, 498-502.

Ma, J., Lei, E., Lei, M., Liu, Y., Chen, T., 2018. Remediation of arsenic contaminated soil using malposed intercropping of Pteris vittata $\mathrm{L}$. and maize. Chemosphere 194, 737-744.

Ma, L.Q., Komar, K.M., Tu, C., Zhang, W., Cai, Y., Kennelley, E.D. 2001. A fern that hyperaccumulates arsenic. Nature 409, 579 579.

Manara, A., Fasani, E., Furini, A., DalCorso, G., 2020. Evolution of the metal hyperaccumulation and hypertolerance traits. Plant, Cell \& Environment 43, 2969-2986.

Mathews, S., Ma, L.Q., Rathinasabapathi, B., Stamps, R.H., 2009. Arsenic reduced scale-insect infestation on arsenic hyperaccumulator Pteris vittata L. Environmental and Experimental Botany 65, 282-286.

Mehltreter, K., Rojas, P., Palacios-Rios, M., 2003. Moth larvaedamaged giant leather-fern Acrostichum danaeifolium as host for secondary colonization by ants. American Fern Journal 93, 49-55.

Nagamine, K., Hojoh, K., Nagata, S., Shintani, Y., 2019. Rearing Theretra oldenlandiae (Lepidoptera: Sphingidae) larvae on an artificial diet. Journal of Insect Science 19, 5.

Purwani, K.I., Ermavitalini, D., Nurhidayati, T., Nurhatika, S., Bagus, T., 2015. Exploration of Potential Plants As a Bio-Insecticide at Its Surabaya Campus. In: Setyobudi, R.H., Nuringtyas, T.R., Burlakovs, J., Mel, M., Adinurani, P.G., VincevicaGaile, Z., eds. International Conference on Biological Sciences. Knowledge $E$, Dubai, pp. 662-662.

Ramasamy, S., Sotelo, P., Lin, M.Y., Heng, C.H., Kang, S., Sarika, S., 2020. Validation of a bio-based integrated pest management package for the control of major insect pests on Chinese mustard in Cambodia. Crop Protection (Guildford, Surrey) 135, 8.

Rathinasabapathi, B., Rangasamy, M., Froeba, J., Cherry, R.H., McAuslane, H.J., Capinera, J.L., Srivastava, M., Ma, L.Q., 2007. Arsenic hyperaccumulation in the Chinese brake fern (Pteris vittata) deters grasshopper (Schistocerca americana) herbivory. New Phytologist 175, 363-369.

Sharma, A., Shukla, A., Attri, K., Kumar, M., Kumar, P., Suttee, A., Singh, G., Barnwal, R.P., Singla, N., 2020. Global trends in pesticides: A looming threat and viable alternatives. Ecotoxicology and Environmental Safety 201, 110812.

Skaldina, O., Ciszek, R., Peräniemi, S., Kolehmainen, M., Sorvari, J., 2020. Facing the threat: common yellowjacket wasps as indicators of heavy metal pollution. Environmental Science and Pollution Research International 27, 29031-29042.

Su, Y.H., McGrath, S.P., Zhu, Y.G., Zhao, F.J., 2008. Highly efficient xylem transport of arsenite in the arsenic hyperaccumulator Pteris vittata. New Phytologist 180, 434 441.

Wan, X., Lei, M., Chen, T., Ma, J., 2017a. Micro-distribution of arsenic species in tissues of hyperaccumulator Pteris vittata L. Chemosphere 166, 389-399.

Wan, X., Lei, M., Chen, T., Yang, J., 2017b. Intercropped Pteris vittata L. and Morus alba L. presents a safe utilization mode for arseniccontaminated soil. Science of the Total Environment 579, 14671475.

Watts, M.J., Button, M., Brewer, T.S., Jenkin, G.R.T., Harrington, C.F., 2008. Quantitative arsenic speciation in two species of earthworms from a former mine site. Journal of Environmental Monitoring 10, 753-759.

Zhang, W., Cai, Y., Tu, C., Ma, L.Q., 2002. Arsenic speciation and distribution in an arsenic hyperaccumulating plant. Science of the Total Environment 300, 167-177. 